\title{
Alpha Chemokine
}

National Cancer Institute

\section{Source}

National Cancer Institute. Alpha Chemokine. NCI Thesaurus. Code C20467.

Members of the Alpha-Chemokines are referred to also as the $4 q$ chemokine family because the genes encoding members of this family map to human chromosome 4 q1221. The first two cysteine residues of members of this family are separated by a single amino acids and these proteins, therefore, are called also CXC-Chemokines. Some members of the subgroup of the human CXC-Chemokines are defined by the conserved ELR sequence motif (glutamic acid-leucine-arg inine) immediately preceding the first cysteine residue near the amino-terminal end. Chemokines with an ELR sequence motif have been found to chemoattract and activate primarily neutrophils. Chemokines without the ELR sequence motif appear to chemoattract and activate monocytes, dendritic cells, T-cells, NK-cells, B-lymphocytes, basophils, and eosinophils. 